Dept. of Internal Medicine,

Fac. of Vet. Med., Alexandria University.

\title{
CONCURRENT INFECTION WITH INTERNAL PARASITES AND SKIN SCALY LESIONS IN FRIESIAN CALVES AND EFFICACY OF TREATMENT \\ (With 10 Tables)
}

By

\section{A.A. MAHMOUD; N.M. BAKIR*; H.A. HAMOUDA*}

*Animal Health Research Institute, Damanhor.

(Received at 24/5/2008)

توافث الإصابة بالديدان الداخلية والأمراض الجلدية ذات القشور



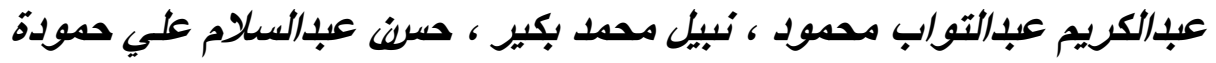

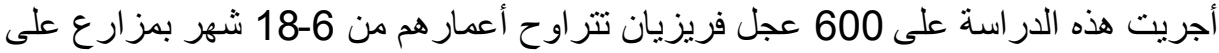

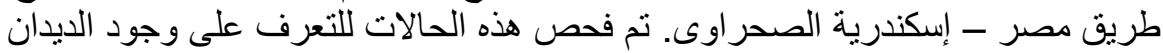

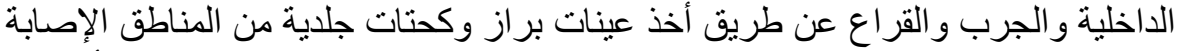

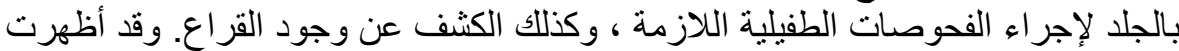


الطفيليات شائعة الإصابة هي ترايكوسترنجليس بنسبة استرتاجيا بمعدل 23.2 \% و نيماتوديرس 18.8 و 18.8 \% و أيضاً كانت الإصابة بالاديدان الكبدية

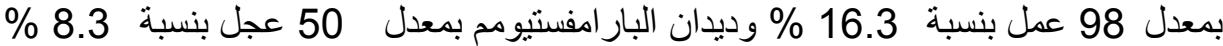

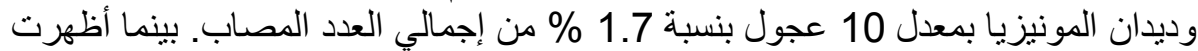

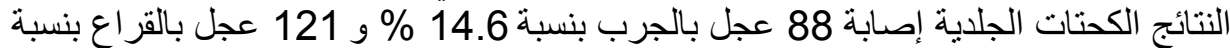



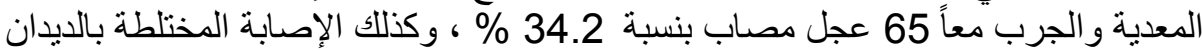

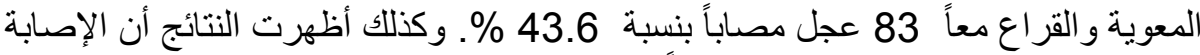
المختلطة بين الديدان الكبدية و الجرب معاً بمعدل 60 عجل بعل بنسبة 61 ع 61 \% و والإصابة بالايدان

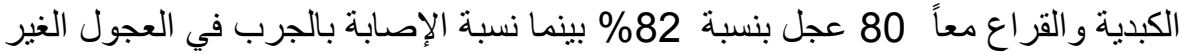

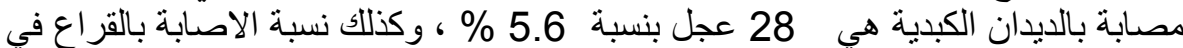

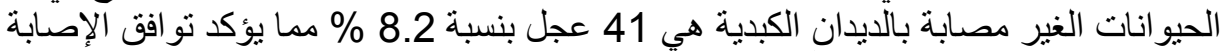

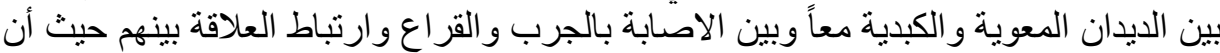

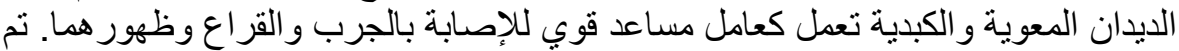

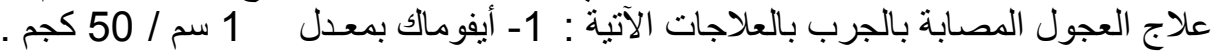

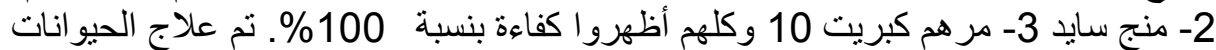

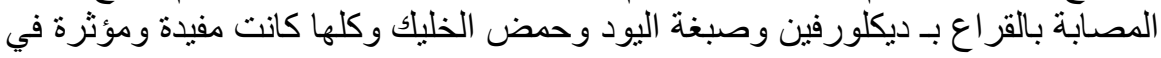




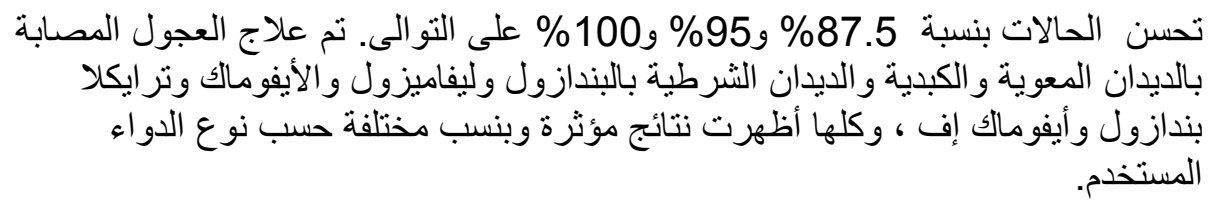

\section{SUMMARY}

Six hundred Friezian calves of 6-18 months age were stocked in different private farms at Alexandria desert road Egypt were clinically examined, feacal samples and skin scraping were collected for detection of internal parasites, ring worm and mange infestation. Feacal examination revealed that the prevalence rate of gastrointestinal nematode in examined animals was (31.7\%). The most prevalent nematodes recovered by larval cultural were Trichotronglus spp. (32.1\%), Haemonchus spp. (27.9\%), Oestertagia spp. (23.2\%), and Nematodirus (16.8\%). While the infestation rate of Fasciola spp, para mphystomum and moneizia were $16.3 \%, 8.3 \%$ and $107 \%$ respectively. Examination of skin scraping revealed that the prevalence rate of mange was $(14.7 \%)$. The mycological culture revealed isolate of Trichophyton spp. (20.2\%). Mixed infestation of gastrointestinal nematodes and skin lesion due to infestation by mange and infection by ringworm were $34.2 \%$ and $43.6 \%$ respectively. Mixed infestation of Fasciola spp. and skin lesion which occur due to infestation by mange and by ringworm was $61 \%$ and $82 \%$ respectively. The efficacy of drugs as Ivomec F, Mangecide and Sulpher ointment $10 \%$ treated mange was $100 \%$ while the efficacy of drugs in calves infected by ring worm were Dichlorphen $1.5 \%$. Tincture iodine $3 \%$ and glacial acitic acid $3 \%$ was $87.5 \%, 95 \%$ and $100 \%$ respectively. The efficacy of drugs used for selected calves wormer in this study were, Abendazole in parasitic gostrointestinal, Fascioala and Moneizia infestation was 96\%, $83.3 \%$ and $100 \%$ respectively, while levamisol and Ivomec have $100 \%$ efficacy in treatment of parasitic gostrointestinal. The treatment of Fasciola by triclabendazole and Ivomec $\mathrm{F}$ was $90 \%$ and $85 \%$ respectively.

Key words: calves, skin lesions, parasitism, ringworm

\section{INTRODUCTION}

Parasitic infestations causes an economical losses among cattle. Fasciola gigantica is considered as the most important one and it seriously affects animals health in Egypt. Economical losses are huge due to drop in meat and milk production arised from feeding of young flukes on hepatic cells, anemia and emaciation produced by the daily 
loss of about $50 \mathrm{ml}$ blood per fluke which was reported by (Abd El-Gawad et al., 1989).

Mange is a common cause economic losses include weight losses, decrease milk production and increased susceptibility to other diseases (Urquhart et al., 1988).

Outbreaks of mange usually occure in housed cattle, as sarcoptic mange is highly contagious and spread by close contact. Infestation in cattle starts usually on the sparsely haired part of the body such as the head and neck or sacral region (Kettle, 1984).

Under certain conditions, mange can spread all over the body of cattle. Mild infestations showed scaly skin with little hair loss, but in severe cases, the skin becomes thickened and wrinkled (hyperkeratosis) and there is a marked loss of hair. The altered skin functions and the intense priorities in cattle may result in considerable economic losses (Kutzer, 2000).

Ringworm is the most commonly seen in calves, particularly in the region around the eyes, although generalized skin lesions on the body can develop. Lesions are usually discrete, scaly patches of hair loss with a grey crust formation. Some thickly crusted with pus. Ring worm is more common as a herd health problem in winter months and also in tropical climate due to high humidity (Younes 2002).

The aim of the present work is to spotalight on:

1 - The relationship between the infestation by internal parasites and scaly skin lesions (mange and ring worm).

2 - The efficacy of the treatment.

\section{MATERIALS and METHODS}

Animals:

A total 600 Friezian calves of 6-18 months age belonging to a private farm at Alexandria desert road Egypt were used in this study.

\section{Samples and methods}

\section{A - Feacal samples:}

Feacal samples of 600 Friezian calves were collected from the rectum and examined microscopically using concentration flotation and concentration sedimentation techniques, the feacal culture and larval differentiation carried out according to (Georgi 1980).

\section{B - Skin scraping:}

Samples were collected from the periphery of lesions, taking no more than $10 \%$ of the total area of the lesion at any sampling time, scrapings were made using a sharp flat scalpel from an area 
approximately $3 \times 3 \mathrm{~cm}$. A part of each sample was placed in a few drops of Potassium Hydroxide $20 \%$ solution on a slide covered with a cover slid and examined microscopically after 30 minute without its dryness for the presence of fungal elements (Emmons et al., 1977).

The second-third part of skin scraping was inoculated into the surface of Sabouroud's Dextrose Agar media to which Chlormphenicol $(250 \mathrm{mg} / \mathrm{L})$ and Actidione $(500 \mathrm{mg} / \mathrm{L})$ were added. The inoculated tubes incubated at $25-30^{\circ} \mathrm{C}$ for 2 weeks. The growing organisms were examined for cultural characteristics and spore morphology was studied by slide culture method according to Freg et al. (1979).

Approximately the last-third of each skin scraping was moserated in $10 \%$ potassium hydroxide in a hot water (not boiled) until clearing of the skin tissues, cooling them, centrifuged and examined microscopically for detection of mites (Barth and Visse 1985).

\section{Treatment:}

Treatment were carried out by using different drugs for internal parasites [Albendazole $10 \% 3 \mathrm{ml} / 45$ K.g B.W Orally, Levacide $10 \%$ (levamisol Hcl $10 \%$ ), 10ml/100 K.g B.W S/C, Ivomec $1 \mathrm{ml} / 50$ K,.g B.W subcut . Tricla-bendazole (Fasinex) $10 \mathrm{ml} / 100 \mathrm{~K} . \mathrm{g} \mathrm{B.W}$. orally.

Efficacy of drugs in mange is carried by using Ivomec $1 \mathrm{ml}$ $50 \mathrm{~K}$, g B.W s/c twice injection with week interval, mangcide applied locally daily for 5 days and sulpher ointment $10 \%$ applied locally daily for 5 days.

Different drugs are used in treatment of ring worm (Di-chlorophan 1.5\%, spray for 2 weeks, tincture iodine 3\% applied for 3 weeks and glacial acetic acid $3 \%$ locally for 10 days, all animals were treated orally by potassium iodide $2 \mathrm{mg} / \mathrm{k.g}$ B.w for 10 days, $\mathrm{AD}_{3} \mathrm{E}$ (10 m/calves) i.m, twice injection.

\section{RESULTS}

Some calves were suffering from diarrhea, rough coat, loss of weight, emaciation and unthriftness. Skin affection appeared on some cases in addition to the previous signs. There were itching manifested by bitting and rubbing of the infested skin; the skin of the effected area was thickened with some fissures as well as denuded crusts; the hair was broken and extirpated.

Results of the parasitological examination of feacal samples revealed that gastrointestinal nematodes Fasciola, Paramphystomum and Moneizia were $31.7 \%, 16.3 \%, 8.3 \%$ and $1.7 \%$ respectively. While the results of feacal culture for larval differentiation revealed the infestation 
of these calves with Trichostrongylus spp., Heamonchus spp., Oestartagia spp. and Nematodiurus spp (Table 2).

Skin scraping examination recorded 88 calves were infested with mange $(14.1 \%)$ and 121 calves infected with ring worm $(20.2 \%)$ (Table 3).

The percentage of infestation with mange and ring worm in PGI infested calves was high $34.2 \%$ and $43.6 \%$ respectively in which 65 managed calves and 83 infected ring worm calves out of 190 infested with parasitic gastrointestinal one, while it was low 5.6\% and $9.3 \%$ respectively (23 managed calves and 38 infected ring worm out of 410 PGI free calves) (Tables 4, 5).

The percentage of infestation with mange and infected ring worm in fasciolated calves was high $61 \%$ and $82 \%$ respectively in which 60 managed calves and 80 infected ring worm calves out of 98 fasciolated calves. While it was low $5.6 \%$ and $8.2 \%$ respectively where 28 manged calves and 41 infected ring worm in out 502. Fasciola free calves (Tables $6,7)$.

\section{Treatment:}

Ivomec, magnified and sulpher ointment $10 \%$ are used in treatment of manged calves and show $100 \%$ cure rate (Table 8). Treatment of ring worm by different drugs dichlorophen $1.5 \%$, tincture iodine $3 \%$ and glacial acetic acid show $87.5 \%, 95 \%$ and $100 \%$ curity respectively (Table 9).

Efficacy of drugs in selected calves wormer show that Albendazol were $96 \%$ of PGI $88.3 \%$ of Fasciola and $100 \%$ in moniezia levamisol and Ivomec show $100 \%$ in both drug in parasitic gastrointestinal. Triclabendazole and Ivomec F cure $90 \%$ and $85 \%$ respectively from fasciolated calves.

Table 1: Results of parasitological examination of feacal samples.

\begin{tabular}{|c|c|c|c|c|c|c|c|c|c|c|c|c|}
\hline \multirow{2}{*}{$\begin{array}{l}\text { Total No. } \\
\text { of } \\
\text { examined } \\
\text { animals }\end{array}$} & \multicolumn{2}{|c|}{ Fasciola spp } & \multicolumn{2}{|c|}{ Paramphystomum } & \multicolumn{2}{|c|}{ Moneizia } & \multicolumn{2}{|c|}{ Parastic G.I } & \multicolumn{2}{|c|}{$\begin{array}{l}\text { Mixed } \\
\text { infestation } \\
\text { Fasciola } \\
\text { and P.G.I }\end{array}$} & \multicolumn{2}{|c|}{$\begin{array}{c}\text { Mixed infestation } \\
\text { Paramphystomum } \\
\text { and P.G.I }\end{array}$} \\
\hline & No. & $\%$ & No. & $\%$ & No. & $\%$ & No. & $\%$ & No. & $\%$ & No. & $\%$ \\
\hline 600 & 98 & 16.3 & 50 & 8.3 & 10 & 1.7 & 190 & 31.7 & 53 & 8.8 & 35 & 5.8 \\
\hline
\end{tabular}


Table 2: Results of larval differentiation of feacal culture.

\begin{tabular}{|c|c|c|c|c|c|c|c|c|}
\hline \multirow{2}{*}{$\begin{array}{c}\text { No. of } \\
\text { infested } \\
\text { calves }\end{array}$} & \multicolumn{2}{|c|}{ Trichostrongylus } & \multicolumn{2}{|c|}{$\begin{array}{c}\text { Heamonchus } \\
\text { spp. }\end{array}$} & \multicolumn{2}{|c|}{ Oestrtagia spp. } & \multicolumn{2}{|c|}{$\begin{array}{c}\text { Nematodirus } \\
\text { spp. }\end{array}$} \\
\cline { 2 - 9 } & No. & $\%$ & No. & $\%$ & No. & $\%$ & No. & $\%$ \\
\hline 190 & 61 & 32.1 & 53 & 27.9 & 44 & 23.2 & 32 & 18.8 \\
\hline
\end{tabular}

Table 3: Results of examination of skin scraping.

\begin{tabular}{|c|c|c|c|c|}
\hline $\begin{array}{c}\text { Total No. of } \\
\text { examined } \\
\text { animals }\end{array}$ & \multicolumn{2}{|c|}{$\begin{array}{c}\text { No. of animals infested } \\
\text { with mite }\end{array}$} & \multicolumn{2}{|c|}{$\begin{array}{c}\text { No. of animals infected with } \\
\text { ringworm }\end{array}$} \\
\hline 600 & No & $\%$ & No & $\%$ \\
\hline
\end{tabular}

Table 4: Results of manged calves from PGI infested and PGI free calves.

\begin{tabular}{|c|c|c|c|c|c|c|}
\hline $\begin{array}{c}\text { Total No. } \\
\text { of ex. } \\
\text { Calves }\end{array}$ & $\begin{array}{c}\text { No. of } \\
\text { PGI } \\
\text { infested } \\
\text { Calves }\end{array}$ & $\begin{array}{c}\text { No. of manged } \\
\text { calves } \\
\text { recovered from } \\
\text { PGI infested } \\
\text { Calves }\end{array}$ & $\begin{array}{c}\text { Positive } \\
\%\end{array}$ & $\begin{array}{c}\text { No. of } \\
\text { PGI free } \\
\text { calves }\end{array}$ & $\begin{array}{c}\text { No. of manged } \\
\text { calves recovered } \\
\text { from PGI free } \\
\text { calves }\end{array}$ & $\begin{array}{c}\text { Positive } \\
\%\end{array}$ \\
\hline 600 & 190 & 65 & $34.2 \%$ & 410 & 23 & $5.6 \%$ \\
\hline
\end{tabular}

Table 5: Results of ringworm infected calves recovered from PGI infested and PGI free calves.

\begin{tabular}{|c|c|c|c|c|c|c|}
\hline $\begin{array}{c}\text { Total } \\
\text { No. } \\
\text { of ex. } \\
\text { Calves }\end{array}$ & $\begin{array}{c}\text { No. of PGI } \\
\text { infested } \\
\text { Calves }\end{array}$ & $\begin{array}{c}\text { No. of ringworm } \\
\text { infected calves } \\
\text { recovered from } \\
\text { PGI infested } \\
\text { Calves }\end{array}$ & $\begin{array}{c}\text { Positive } \\
\%\end{array}$ & $\begin{array}{c}\text { No. of } \\
\text { PGI } \\
\text { free } \\
\text { calves }\end{array}$ & $\begin{array}{c}\text { No. of ringworm } \\
\text { infected calves } \\
\text { recovered from } \\
\text { PGI free calves }\end{array}$ & $\begin{array}{c}\text { Positi } \\
\text { ve } \\
\%\end{array}$ \\
\hline 600 & 190 & 83 & 43.6 & 410 & 38 & $\begin{array}{c}9.3 \\
\%\end{array}$ \\
\hline
\end{tabular}


Table 6: Results of manged calves recovered from fasciolated and fasciola free calves.

\begin{tabular}{|c|c|c|c|c|c|c|}
\hline $\begin{array}{c}\text { Total } \\
\text { No. } \\
\begin{array}{c}\text { Of ex. } \\
\text { Calves }\end{array}\end{array}$ & $\begin{array}{c}\text { No. of } \\
\text { fasciola } \\
\text { infested } \\
\text { Calves }\end{array}$ & $\begin{array}{c}\text { No. of manged } \\
\text { calves recovered } \\
\text { from fasciola } \\
\text { infested Calves }\end{array}$ & $\begin{array}{c}\text { Positive } \\
\%\end{array}$ & $\begin{array}{c}\text { No. of } \\
\text { fasciola } \\
\text { free calves }\end{array}$ & $\begin{array}{c}\text { No. of manged } \\
\text { calves recovered } \\
\text { from fasciola } \\
\text { free calves }\end{array}$ & $\begin{array}{c}\text { Positive } \\
\%\end{array}$ \\
\hline 600 & 98 & 60 & $61 \%$ & 502 & 28 & $5.6 \%$ \\
\hline
\end{tabular}

Table 7: Results of ringworm infected calves recovered from fasciola and fasciola free calves

\begin{tabular}{|c|c|c|c|c|c|c|}
\hline $\begin{array}{c}\text { Total } \\
\text { No. } \\
\text { Of ex. } \\
\text { Calves }\end{array}$ & $\begin{array}{c}\text { No. of } \\
\text { fasciola } \\
\text { infested } \\
\text { Calves }\end{array}$ & $\begin{array}{c}\text { No. of ringworm } \\
\text { infected calves } \\
\text { recovered from } \\
\text { fasciola infested } \\
\text { Calves }\end{array}$ & $\begin{array}{c}\text { Positive } \\
\%\end{array}$ & $\begin{array}{c}\text { No. of } \\
\text { fasciola } \\
\text { free calves }\end{array}$ & $\begin{array}{c}\text { No. of ringworm } \\
\text { infected calves } \\
\text { recovered } \\
\text { fasciola from } \\
\text { free calves }\end{array}$ & $\begin{array}{c}\text { Positive } \\
\%\end{array}$ \\
\hline 600 & 98 & 80 & $82 \%$ & 502 & 41 & $8.2 \%$ \\
\hline
\end{tabular}

Table 8: Results of efficacy of mangecidal drugs.

\begin{tabular}{|c|c|c|c|c|}
\hline \multirow{2}{*}{\multicolumn{2}{|c|}{$\begin{array}{l}\text { Total infested } \\
\text { No. (88) } \\
\text { Groups } \\
\end{array}$}} & \multirow[t]{2}{*}{ Drug administration } & \multicolumn{2}{|c|}{ Cure rate } \\
\hline & & & \multirow{2}{*}{$\begin{array}{l}\text { No. } \\
30\end{array}$} & \multirow{2}{*}{$\%$} \\
\hline G1 & 30 & $\begin{array}{c}\text { Ivomec } \\
\text { (Twice injection with week interval) }\end{array}$ & & \\
\hline G2 & 30 & $\begin{array}{c}\text { Mangcide ( Benzyl benzoate, Sulpher, Salicylic acid, } \\
\text { Phenol and Tar) applied locally daily } \\
\text { for } 5 \text { days. }\end{array}$ & 30 & 100 \\
\hline G3 & 28 & Sulpher ointment $10 \%$ applied locally daily for 5 days & 28 & 100 \\
\hline
\end{tabular}

Table 9: Results of efficacy of fungicidal drugs.

\begin{tabular}{|c|c|c|c|c|}
\hline \multirow{2}{*}{\multicolumn{2}{|c|}{$\begin{array}{l}\text { Total infected } \\
\text { calves }(120)\end{array}$}} & \multirow{3}{*}{$\begin{array}{l}\text { Drug administration } \\
\text { orophen } 1.5 \% \text { for two weeks }\end{array}$} & \multicolumn{2}{|c|}{ Cure rate } \\
\hline & & & \multirow{2}{*}{$\frac{\text { No. }}{35}$} & \multirow{2}{*}{$\begin{array}{c}\% \\
87.5\end{array}$} \\
\hline G1 & 40 & & & \\
\hline $\mathrm{G} 2$ & 40 & Tincture iodine $3 \%$ for three weeks & 38 & 95 \\
\hline G3 & 40 & $3 \%$ Glacial acetic acid for 10 days & 40 & 100 \\
\hline
\end{tabular}


Table 10: Efficacy of drugs in selected calves wormers.

\begin{tabular}{|l|c|c|c|c|c|c|c|c|c|}
\hline \multirow{2}{*}{$\begin{array}{c}\text { Generic drug } \\
\text { name }\end{array}$} & \multicolumn{3}{|c|}{ PGI } & \multicolumn{3}{c|}{ Fasciola } & \multicolumn{3}{c|}{ Moneizia } \\
\cline { 2 - 11 } & \multicolumn{2}{|c|}{ Total 190 } & \multicolumn{3}{c|}{ Total 98 } & \multicolumn{3}{c|}{ Total 10 } \\
\cline { 2 - 10 } & $\begin{array}{c}\text { No. of } \\
\text { treated }\end{array}$ & Cure & $\%$ & $\begin{array}{c}\text { No. of } \\
\text { treated }\end{array}$ & Cure & $\%$ & $\begin{array}{c}\text { No. of } \\
\text { treated }\end{array}$ & Cure & $\%$ \\
\hline Albendazole & 50 & 48 & 96 & 48 & 40 & 83.3 & 10 & 10 & 100 \\
\hline Levamisol & 50 & 50 & 100 & - & - & - & - & - & - \\
\hline Ivomec & 90 & 90 & 100 & - & - & - & - & - & - \\
\hline Triclabendazole & - & - & - & 20 & 18 & 90 & - & - & - \\
\hline Ivomec F & - & - & - & 20 & 17 & 85 & - & - & - \\
\hline
\end{tabular}

\section{DISCUSSION}

Gastrointestinal nematodes and liver fluke infestation are the major contributors to reduced productivity and can lower the production of meat and milk (Radostits et al., 2000). Mange is one of the most destructive parasitic diseases not only on the skin, but also to general condition of the affected animals (Hourrigan 1979). Ring worm is more common as a herd health problem in winter months, spontaneous recovery is common in cattle, but valuable animals are commonly treated to limit progression of the disease to other members (Emmons et al., 1977).

This investigation revealed the prevalence of gastrointestinal nematodes infestation in naturally infested calves (Table 1) 190 calves $(31.7 \%)$ were infested with gastrointestinal nematodes, 98 calves $(16.3 \%)$ infested with fasciola spp., 50 calves $(8.3 \%)$ infested with paramphystomum and 10 calves $(1.7 \%)$ infested with Moneizia these results agree with Morsy et al. (2005), who recorded fasciola infestation rate among calves (20\%) but disagree with El-Shazly et al. (2002) who reported it $9.73 \%$.

It was observed that the infestation with Paramphystomum (8.3 \%), this results agree with Haridy et al. (2006) who reported Paramphystomum infestation was $10 \%$. The results of larval differentiation of fecal culture of nematodes were Trichostrongylus spp (32.1\%), Heamonchus spp (27\%), Oestertagia spp. (32.2\%) and Nematodirus spp. (16.8 \%) (Table 2). It was obvious that highest susceptibility of calves less than 1.5 years old to parasitic infestation especially PGI that could be explained by incomplete development of 
immune system in young ages and with age progress the immune system can overcome these parasitic infestations and eliminates it from the animal body this agree with Salib (2007).

Results of skin scraping examination recorded in Table (3) reveled that $14.7 \%$ and $20.2 \%$ for mange and ring worm respectively. This result agrees with Gates and Wescott (2000) and Younes (2002).

The mixed infestation of gastrointestinal parasite mange and ring worm were $34.2 \%$ and $43.6 \%$ respectively (65 managed calves and 83 ring worm infected calves respectively out of 190 of parasitic gastrointestinal one) while it was low $5.6 \%$ and $9.3 \%$ respectively in parasitic gasterointestinal free calves (23 manged calves and 38 ring worm infected calves out of 410 one)

Although mixed infestation of fasciola, mange and ring worm were $61 \%$ and $82 \%$ respectively (60 managed calves and 80 ring worm infected calves respectively out of 98 fasciolated calves) while it was low $5.6 \%$ and $8.2 \%$ respectively in fasciola free calves $(28$ manged calves and 41 infected ring worm calves out of 502 of fasciola free calves).

From the obtained results it could be concluded that gastrointestinal and fasciola fluckes may enhance susceptibility of calves to mange and ring worm and predispose to infestation.

Naturally occurring of parasitic diseases in farm animals are frequently caused by concurrent infections with two or more immunobiologically unrelated or remotely related species of parasites (Fakae and Chiejina 1993) while, (Christensen et al., 1987) reported that heterologous parasite interaction in domestic animals may give rise to the prolonged survival and enhanced pathogenicity of one of the concomitant infections. Also Bruer and West (1993), Fritsche et al. (1993) reported that, gastrointestinal nematodes naturally infested with mange. They attributed these results to the nematodes infestation which induces desquamation and sloughing of the epithelium, villous atrophy and consequently decrease absorption mineral and other food nutrients and inappetance.morever, At farm level the factors must be considered in approaching the mange outbreak such as source of infestation, helminth parasite status and general health status (O'Brien 1999).

The efficacy of the treatment was assessed based on healing of the skin lesions and absence of mites on the skin. Table (8) showd that total of 88 calves naturally infected with mange were divided into 3 groups which were group 1 treated with Ivomec F 2 injections subcutaneously at week intervals, and group 2 treated with Mangecide 
applied locally daily for 5 days and group 3 treated with a sulpher ointment $10 \%$ topically applied once daily for a week. Skin scrapings were examined at weekly intervals to determine the efficacy of the treatments. It was shown that the total number of treatments to cure mange was $100 \%$ in all three groups. Ivomec $\mathrm{F}$ provides numerous advantages when used in the form of injection. meanwhile local treatments to be effective the drug must cover the entire integument which may cause side effects such as burning sensation and irrigative dermatitis (Buffect and Dupin 2003). So Ivomec is the most easily effective applied treatment against mange. This result agrees with results obtianed by Bridi et al. (2001) and Patal et al. (2003).

In Table (9) a total of 120 calves infected with ring worm were divided into 3 groups which were treated with dichlorophen $1.5 \%$ for two weeks, tincture iodine $3 \%$ for three weeks and glacial acidic acid for 10 days. Skin scrapings were examined at weekly intervals to determine the efficacy of the treatment. It was shown that, the efficacy of treatments was $87.5 \%, 95 \%$ and $100 \%$ for Dichlorophen,Tincture iodine and Glacial acetic acid respectively. This result agrees with Younes (2002).

Table (10) shows efficacy of drugs in selected cattle wormers where Albendazole effect 96\%, 94.7\% and 100\% on PGI, Fasciola and Moneizia respectively. Levamisol and Ivomec effect $100 \%$ on PGI. These results agree with Gates and Wescott (2000).

Triclabendazole effected on $90 \%$ of liver fluke our results supported by Yehia et al. (2006).

Ivomec $\mathrm{F}$ effected on $85 \%$ of liver flukes agreed by Eisa and Esmail (2003).

\section{REFERENCES}

Abdel-Gawad, A.F.; Soliman, M.A. and Abdel Ghani, A.F. (1981): Diagnosis of immature Fasciola gigantica by interadermal test. J. Egypt. Vet. Assoc., 41 (2): 179-187.

Barth, D. and Visse, M. (1985): Comparison of two methods for counting living mites in skin scrapings. Zentralbi Bacteriol. Mikrobiol. Hyg. Ass. 260-412.

Bridi, A.A.; Carvalho, L.A.; Cramer, L.G. and B. Arrick, R.A. (2001): Efficacy of long-acting formulation of Ivermectin against psorptes ovis in cattle. Vet. Parasitol. (97): 277-283. 
Bruere, A.N. and West, D.M. (1993): The sheep health disease and production. Vet. Assoc., Palmerston North. New Zealand pp. 397

Buffect, M. and Dupin, N. (2003): Current treatments for scabies. Fundamental and Clinical Pharmacology, 17 (2): 217-220.

Christensen, N.O.; Nansen, P.; Fagbemi, B. and Monrod, J. (1987): Hetrologous antagonistic and synergistic interaction between helminthes and protozoan in concurrent experimental infection of mammalin hosts. parasitol. Res. 73: 387-410.

Emmons, C.W.; Binford, C.H. and VTZ. T.P. (1977): Medical Mycology $3^{\text {rd }}$ Ed. Philadelphia lea and febiger.

El-Shazly, A.M.; El-Wafa, S.A; Haridy, F.M.; Soliman, M.; Fifaat, M.M. and Morsy, T.A. (2002): Fascioliasis among live and slaughtered animals in nine centers of Dakahlia governorate. J. Egypt. Sec. Parasitol., 32 (1): 47-57.

Eisa, M.I. and Esmail, M. (2003): Concurrent gastrointestinal nematodes and psorptic mange infestation in sheep: Clinical investigation, some biochemical alteration and treatment. Vet. Med. J. Giza, Vol. 51, No. (2): 177-187.

Hourrigan, J.L. (1979): Spread and detection of psoroptic scabies of cattle in the United States. J.A.V.M.A. (175 (12): 1178-1280.

Hardiy, F.M.; El-Shenawy, G.T. and Morsy, T.A. (2006): Some parasitic flukes infecting farm animals in Al-Santa Center, Gharbia governorate, Egypt. Soc. Parasitol., 36 (1): 259-264.

Georgi, J.R. (1980): Parasitology for Veterinarian $3^{\text {rd }}$. Ed., W.B. Saunders, Philadelphia.

Gates, N.L. and Wescott, R.B. (2000): Riprinted 2000 subject code 120, AEB1742.

Fakae, B.B. and Chiejina, S.N. (1993): The prevalence of concurrent typansome and GIN infection in west African Dwarl sheep and goat in Nigeria. Vet. Parasitol. 49, 313-318.

Freg, D.; Old Friend, R.J. and Bridger, R.C. (1979): A color Atlas of pathogenic fungi wolf medical publication Ltd. London.

Fritche, T.; Kaufmann, J. and Pfister, K. (1993): Parasite spectrum and seasonal epidemiology of GIN of small ruminants in the Gambia. Vet. Parasitol. 49: 271-283.

Kettle, D.S. (1989): Sarcoptes scabiel. In: Medical and Veterinary Entomology. Croom Helm Ltd., London pp. 357-360. 
Kutzer, E. (2000): Raudo des Rindes. In Romme, M., Eckert J., Kutzer, E.; Korting W. Schineder, T. (Eds.), Veterinarmedizinische parasitologie. Parey Buchverl., Berlin, pp 307-311.

Morsy, T.A.; Salem, H.S.; Haridy, F.M; Rifaat, M.M.; Abo-Zenadah, N.Y. and Adel El-Kadi, M. (2005): Farm animals fascioliasis in Ezbet El-Bakly (Tamyia Center) Al Fayoum governorate. Egypt Soc. Parasitol., 35 (3): 825-832.

O'Brien (1999): Treatment of psoroptic mange with reference to epidemiology and history. Vet. Parasitol. 83: 177-185.

Patal, J.S.; Patal, P.R.; Panchasara, H.H. and Brahmaxatri,K. C. (2003): Comparative efficacy of some drugs against sarcoptic mange in buffalo calves. Indian Journal of Vet. Med. Vol. (23), No (2): 90-92.

Radostits, O.M.; Gay, C.C.; Blood, D.C. and Hichelff, K.W. (2000): Veterinary Medicine. A text book of the $9^{\text {th }}$ Ed. W.B. S aunders company Ltd, London, New. York, Philadelphia, Sydney.

Salib, F.A. (2007): Gastrointestinal parasitism and validation of in mediate hypersensitivity for diagnosis of Fasciola gigantica infectation in Egyptian buffaloes. EVMSPJ, Vol. IV (1).

Urquhart, G.M.; Armour, H.; Duncan, J.L.; Dunn, A.M. and Jennings, F.W. (1988): Sarcoptic mange of cattle. In: Veterinary parasitology. Longman Science and Technology, Harlow, p. 186.

Younes of Al-Rawashdeh (2002): Ring worm infection in cattle and horse in Jordan. Acta Vet. Brno. (71): 55-60.

Yehia, O.; Fatma, H. and Somia, A.A. (2006): Prevalence of Fasciola affecting buffaloes in Alexandria province spotlights on Fasciola in buffaloes in Egypt and some other countries, genetic, environmental and public health importance. EVMSPJ, Vol. 111 (1). 